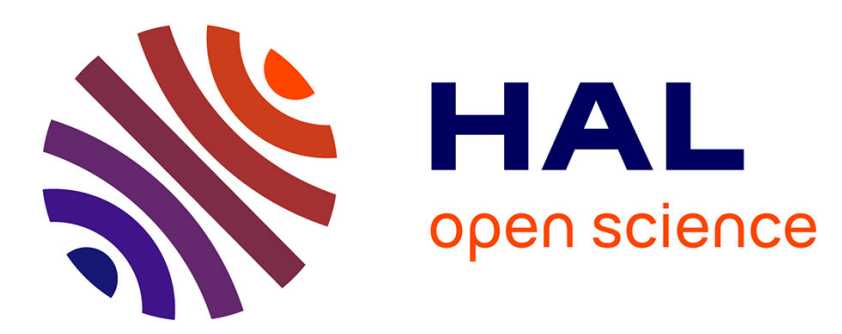

\title{
A DC-DC Converter-Based PEM Fuel Cell System Emulator
}

Daoud Rezzak, Farid Khoucha, Mohamed Benbouzid, Abdelaziz Kheloui, Abdeslam Mamoune

\section{- To cite this version:}

Daoud Rezzak, Farid Khoucha, Mohamed Benbouzid, Abdelaziz Kheloui, Abdeslam Mamoune. A DC-DC Converter-Based PEM Fuel Cell System Emulator. 2011 IEEE POWERENG, May 2011, Malaga, Spain. pp.1-6. hal-00631577

\section{HAL Id: hal-00631577 https://hal.science/hal-00631577}

Submitted on 12 Oct 2011

HAL is a multi-disciplinary open access archive for the deposit and dissemination of scientific research documents, whether they are published or not. The documents may come from teaching and research institutions in France or abroad, or from public or private research centers.
L'archive ouverte pluridisciplinaire HAL, est destinée au dépôt et à la diffusion de documents scientifiques de niveau recherche, publiés ou non, émanant des établissements d'enseignement et de recherche français ou étrangers, des laboratoires publics ou privés. 


\title{
A DC-DC Converter-Based PEM Fuel Cell System Emulator
}

\author{
Daoud Rezzak, Farid Khoucha, Mohamed Benbouzid, Abdelaziz Kheloui and Abdeslam Mamoune
}

\begin{abstract}
The Proton Exchange Membrane Fuel Cell (PEMFC) is being investigated as an alternate power source for various applications as transportation and emergency power supplies. Fuel cell systems are characterized by high costs and complex auxiliary devices. For this reason, a fuel cell emulator can be used as a suitable and economic alternative to a real one for developing and testing a fuel cell power conditioning system. The fuel cell emulator must be able to reproduce the FC nonlinear output voltage-current characteristic.

This paper proposes then a possible solution to emulate a PEMFC system by using a DC-DC converter. The fuel cell system, including all its auxiliaries and related control systems, is emulated by a full-bridge converter experimentally achieved and controlled in the DSP2812 environment. The converter-based system allows the behavior of any fuel cell to be easily emulated and can be used in laboratory as a low-cost system for design and experimental purposes since only a DC-DC control modification is necessary.
\end{abstract}

Index Terms-Fuel Cell System (FCS), Proton Exchange Membrane Fuel Cell (PEMFC), Fuel Cell Emulator (FCE).

\section{INTRODUCTION}

A fuel cell is a generator that converts directly the internal energy of a fuel into electrical energy using an electrochemical process. In contrast to classical electricity generation system, such as heat engines, the theoretical electrical generation efficiency of a fuel cell is very high, and by-products are few pollutants (usually only the water). If hydrogen is produced from clean energy sources, this makes fuel cells an attractive and clean alternative to fossil energy mostly for reasons of pollution and efficiency, especially in automotive applications. Nowadays, the fuel cell research is a very active field. In the last ten years, researches for PEMFC systems have made great improvements of its low working temperature.

Indeed, the fuel cell is an open reactor where hydrogen (or reformed gas) and oxygen (or air) are fed at the inlet of the fuel cell stack depending on the electrical needs, and the byproduct is evacuated at the outlet of the stack. The heat generated from the entropy variation during the electrochemical reaction and the associated irreversible heat sources is also evacuated by a cooling system.

D. Rezzak and A. Kheloui are with the Electrical Engineering Department, Polytechnic Military Academy, 16111 Algiers, Algeria.

F. Khoucha, M.E.H. Benbouzid and A. Mamoune are with the University of Brest, EA 4325 LBMS, Rue de Kergoat, CS 93837, 29238 Brest Cedex 03, France (e-mail: Mohamed.Benbouzid@univ-brest.fr). F. Khoucha is also with the Electrical Engineering Department, Polytechnic Military Academy, 16111 Algiers, Algeria.
In some conditions, the inlet gas should be heated and/or humidified before entering the stack, which requires recovery of water and heat from the outlet of the fuel cell stack.

All these requirements mentioned above are achieved by means of the fuel cell auxiliaries. These auxiliaries are one of the key factors for the efficiency and the durability of a fuel cell system. The auxiliaries design, the control strategies, should be adapted for the fuel cell stack operation characteristics and, also validated by tests performed with the fuel cell stack. Even though, there are important needs of a real fuel cell stack for fuel cell system auxiliaries performance tests and validations, the utilization of a fuel cell stack in such a system validation process still impose some drawbacks: the cost of fuel cell system tests are expensive (e.g., hydrogen consumption), the lifetime of a fuel cell stack is still limited, the fuel cell stack can be damaged during the tests if the auxiliaries are not well designed, and so on [1].

A possible way to reproduce the behavior of a renewable source, whose electrical characteristic lies on a V-I plane (as in the case of a fuel cell), is to use the V-I curve as a signal reference to suitably control a switching DC/DC converter. All these considerations suggest that any renewable source should be replaced by a hardware system capable of copying its behavior accurately. This hardware system is called emulator.

In contrast, the advantages of using a fuel cell stack emulator to test auxiliaries are obvious: the emulated fuel cell stack power can be configured to different value using the same emulator, depending on the specify fuel cell stack to be emulated; the limit operating scenario, such as stack short circuits, stack overheats, can be emulated during the tests, without damaging a real fuel cell stack [1-4].

In this paper a $\mathrm{DC} / \mathrm{DC}$ full bridge converter circuit is presented. The DC/DC converter, suitably driven, can accurately describe the current voltage characteristic of a fuel cell. In general its hardware structure, if the source modeling is correctly known and implemented, can reproduce any renewable source with rated data compatible with those of the DC/DC converter.

\section{Fuel CELl SyStem Model}

The electrochemical reaction at the membranes is assumed to occur instantaneously. The fuel cell stack (st) model contains four interacting sub-models: the stack voltage model, the anode flow model, the cathode flow model, and the membrane hydration model. It is assumed that the stack temperature is constant at $80^{\circ} \mathrm{C}$. The voltage model contains an equation to calculate stack voltage based on fuel cell pressure, temperature, reactant gas partial pressures and membrane humidity. 


\section{A. Fuel Cell Voltage}

PEMFCs combine hydrogen and oxygen over a platinum catalyst to produce electrochemical energy with water as the byproduct. Figure 1 shows the (V-I) characteristic of a typical single cell operating at room temperature and normal air pressure [5]. The variation of individual cell voltage is found from the maximum cell voltage (or EMF) and the various voltage losses. Multiple factors contribute to the irreversible losses (voltage drop) in real fuel cell that cause the cell voltage to be less than its ideal potential [6]. The losses, which are also called polarization, irreversibility, or over voltage, over potential, originate primarily from three sources: a) activation polarization, b) ohmic polarization, and c) concentration (mass transport) polarization. Each of these is associated with a voltage drop and they are dominant in different regions of current density. Fig. 1 shows the different regions and the corresponding polarization effects. The ideal voltage is the maximum voltage that each cell in the stack can produce at a given temperature with the partial pressure of the reactants and products known. The output voltage of a single cell can be given by [6]

$v_{f c}=E-v_{a c t}-v_{o h m}-v_{c o n c}$

where $E$ is the thermodynamic potential of the cell, which represents the reversible voltage; $v_{a c t}$ is the activation overpotential, caused by the activation of the anode and the cathode (a measure of the voltage drop of the electrodes); $v_{\text {ohm }}$ is the ohmic overpotential which takes into account the resistances during conduction of the protons through the solid electrolyte and the electrons through their path and $v_{\text {conc }}$ is the concentration overpotential, which considers the voltage drop caused by the reduction of concentration of reactants gases or, alternatively, by the transport of masses of oxygen and hydrogen. In synthesis, $E$ represents the no-load voltage, while the sum of all the other terms gives the reduction of the useful voltage $v_{f c}$ achievable at the cell terminals, when a certain load current is required.

A higher output voltage is obtained by connecting $n$ cells in series.

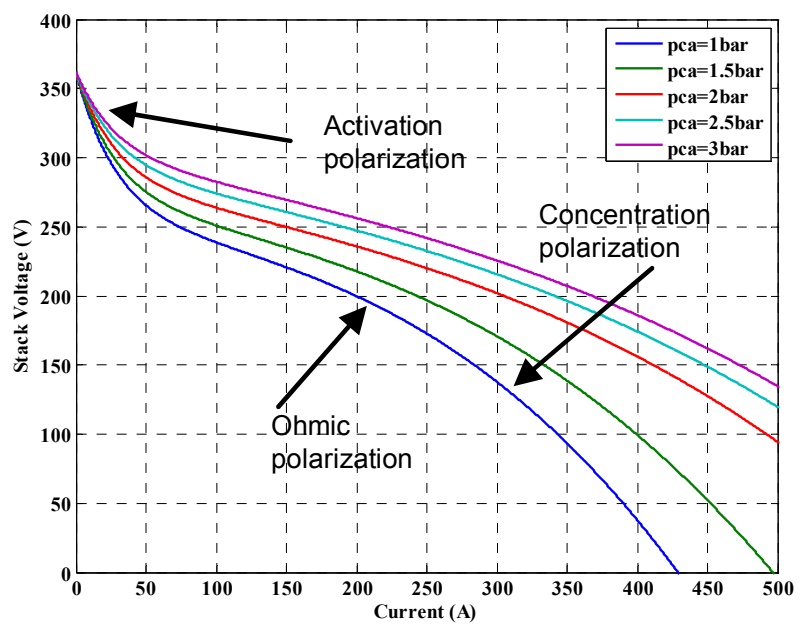

Fig. 1. Fuel cell polarization curve fitting results at $80^{\circ} \mathrm{C}$. $v_{s t}=n v_{f c}$

1) Cell reversible voltage. The reversible voltage or the cell open circuit voltage $E$ is computed using the energy balance between reactants and products, considering the possible variations of temperature from the standard value of $T_{f c 0}=-248^{\circ} \mathrm{K}\left(25^{\circ} \mathrm{C}\right)[1]$.

$$
\begin{aligned}
E=1.229 & -0.85 \times 10^{-3}\left(T_{f c}-298.15\right) \\
& +4.3085 \times 10^{-5} T_{f c} \times\left[\ln p_{H 2}+\frac{1}{2} \ln p_{O 2}\right]
\end{aligned}
$$

Where $T_{f c}$ is the fuel cell temperature $\left({ }^{\circ} \mathrm{K}\right), p_{H 2}$ and $p_{O 2}$ are respectively, the hydrogen and oxygen partial pressures (atm).

2) Activation overpotential. The activation overpotential $v_{a c t}$ can be expressed by [1-9]

$v_{a c t}=v_{0}+v_{a}\left(1-e^{-c_{1} i}\right)$

where $v_{0}$ is the voltage drop at zero current density, $v_{a}$ and $c_{1}$ are constants. The values of these last parameters and their dependency on the oxygen partial pressure and temperature can be determined from a nonlinear regression of experimental data (4).

3) Ohmic voltage drop. The ohmic voltage drop $v_{\text {ohm }}$ is caused by the electrons transfer through the collecting plates and the carbon electrodes, and by the protons transfer through the solid membrane. It is expressed by

$v_{\text {ohm }}=i R_{\text {ohm }}$

where $R_{\text {ohm }}$ is the internal electrical resistance. This resistance strongly depends on the membrane humidity and the cell temperature [10-11]. It can be written as a function of the membrane conductivity $\sigma_{m}$ as

$R_{o h m}=\frac{t_{m}}{\sigma_{m}}$

where $t_{m}$ is the thickness of the membrane. The membrane conductivity is a function of the membrane water content $\lambda_{m}$ and fuel cell temperature. A value of $\lambda_{m}$ between 0 and 14 corresponds to the relative humidity of $0 \%$ and $100 \%$, respectively [1]. Its variation with humidity and temperature is in the form of [8-12]

$\sigma_{m}=\left(b_{11} \lambda_{m}-b_{12}\right) \exp \left(b_{2}\left(\frac{1}{303}-\frac{1}{T_{f c}}\right)\right)$

The coefficients $b_{11}, b_{12}$ and $b_{2}$ are usually empirically determined.

4) Concentration overpotential. The mass transport modifies the concentration both of oxygen and hydrogen, 
which causes the reduction of the partial pressures of the gases. The reduction of the partial pressures of gases depends on the load current and the characteristics of the cell. To define this voltage drop term, a maximum current density $i_{\max }$ is defined, with which the cell works at the same rate of the maximum supply speed. On this basis, the concentration overpotential $v_{\text {conc }}$ can be expressed by [12]

$$
v_{\text {conc }}=i\left(c_{2} \frac{i}{i_{\max }}\right)^{c_{3}}
$$

where $c_{1}, c_{3}$ and $i_{\max }$ are constants that depend on the temperature and the reactant partial pressure and can be empirically determined. The parameter $i_{\max }$ is the current density that causes precipitous voltage drop.

\section{B. Air Management}

The stack air supply system is composed of a centrifugal compressor, a supply manifold, cathode channels and a return manifold as shown in Fig. 2. The compressor supplies the air flow. The supply manifold, cathode channels and return manifold all act as a gas storage volume. The end of the return manifold connects to atmosphere through an actuator valve. The compressor dynamics is governed by its inertia

$J_{c p} \frac{d \omega_{c p}}{d t}=\left(\tau_{c m}-\tau_{c p}\right)$

where $J_{c p}$ is the compressor inertia, $\omega_{c p}$ is the compressor speed, $\tau_{c m}$ and $\tau_{c p}$ are compressor motor torque and compressor load torque, respectively. The compressor speed together with the downstream pressure, i.e. supply manifold pressure $p_{s m}$, influence different air flow rates through the compressor $W_{c p}$.

The compressor motor torque is calculated using a static motor equation

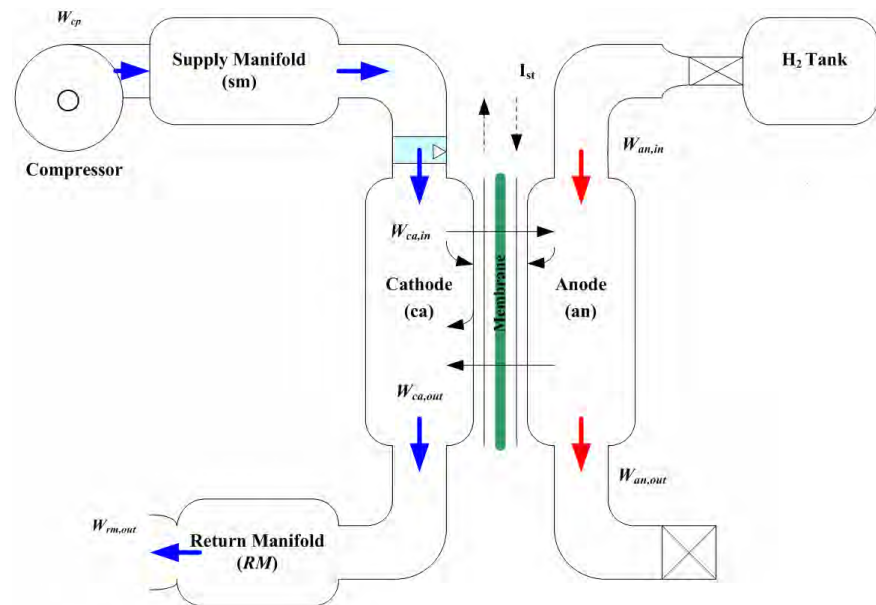

Fig. 2. Air management system where $k_{t}, R_{c m}$ and $k_{v}$ are the motor constants and $\eta_{c m}$ is the motor mechanical efficiency.

$\tau_{c m}=\eta_{c m} \frac{k_{t}}{R_{c m}}\left(v_{v m}-k_{v} \omega_{c p}\right)$

The torque required to drive the compressor is calculated using the thermodynamic equation

$$
\tau_{c p}=\frac{c_{p}}{\omega_{c p}} \frac{T_{a t m}}{\eta_{c p}}\left[\left(\frac{p_{s m}}{p_{a t m}}\right)^{\frac{\gamma-1}{\gamma}}-1\right] W_{c p}
$$

where $\gamma$ is the ratio of the air specific heats, $C_{p}$ is the constant pressure specific heat capacity of air, $\eta_{c p}$ is the compressor efficiency, $p_{a t m}$ and $T_{a t m}$ are respectively the atmospheric pressure and temperature.

The relation between the compressor speed, the downstream pressure and the compressor air flow rate is governed by the compressor flow map, as shown in Fig. 3. The compressor air flow enters into the supply manifold and influences the changes in the pressure inside the supply manifold through mass and energy conservation laws.

$\left\{\begin{array}{l}\frac{d m_{s m}}{d t}=W_{c p}-W_{s m, o u t} \\ \frac{d p_{s m}}{d t}=\frac{\gamma R_{a}}{V_{s m}}\left(W_{c p} T_{c p, o u t}-W_{s m, o u t} T_{s m}\right)\end{array}\right.$

Where $m_{s m}$ is the air mass in the supply manifold and $W_{s m, o u t}$ is the air flow out of the supply manifold into the stack cathode volume which is a function of the supply manifold pressure. $V_{s m}$ is the supply manifold volume, $R_{a}(\mathrm{Nm} / \mathrm{K})$ is the air gas constant and $\gamma$ is in air case 1.4 .

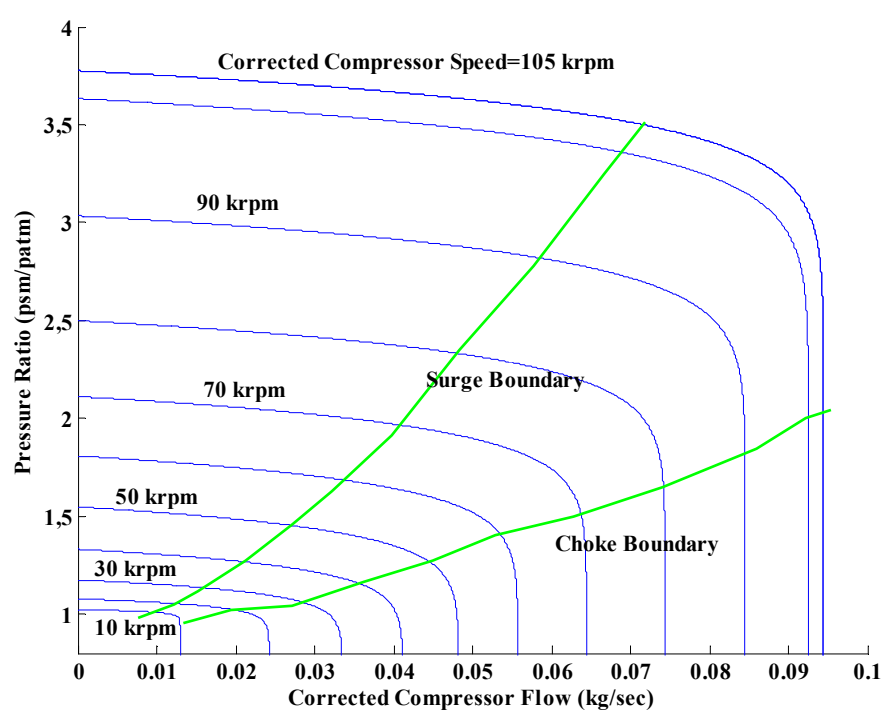

Fig. 3. Compressor flow map. 
$T_{c p, o u t}$ and $T_{s m}$ are the temperature of the air at compressor outlet and that of the air inside the supply manifold, respectively. They are calculated using thermodynamic principles and the ideal gas law.

The change in supply manifold pressure affects the rate of air entering the stack cathode through the linear nozzle equation

$W_{\text {sm,out }}=k_{\text {sm,out }}\left(p_{s m}-p_{c a}\right)$

where $k_{\text {sm,out }}$ is the supply manifold nozzle constant. This air flow rate into the cathode then affects the oxygen level in the cathode, and therefore affects the stack voltage, and the stack power output.

The dynamics of the oxygen level in the cathode is governed by the mass conservation law. There are three states in the cathode volume model, namely the oxygen mass $m_{O 2, c a}$, the nitrogen mass $m_{N 2, c a}$, and the vapor mass $m_{w, c a}$. Their state equations are

$$
\left\{\begin{array}{l}
\frac{d m_{O 2, c a}}{d t}=W_{O 2, c a, \text { in }}-W_{O 2, \text { ca,out }}-W_{O 2, \text { reacted }} \\
\frac{d m_{N 2, c a}}{d t}=W_{N 2, c a, \text { in }}-W_{N 2, \text { ca,out }} \\
\frac{d m_{v, c a}}{d t}=W_{v, \text { ca, in }}-W_{v, \text { ca,out }}+W_{v, \text { ca,gen }}+W_{v, \text { membr }}+W_{l, c a, \text { out }}
\end{array}\right.
$$

Where $W_{O 2, c a, \text { in }}$ is the oxygen gas mass flow rate entering the cathode, $W_{O 2, \text { ca, out }}$ is the oxygen gas mass flow rate leaving the cathode, $W_{N 2, \text { ca, in }}$ is the nitrogen gas mass flow rate entering the cathode, $W_{N 2 \text {, ca, out }}$ is the nitrogen gas mass flow rate leaving the cathode, $W_{v, c a, i n}$ is the vapor mass flow rate entering the cathode, $W_{v, \text { ca,out }}$ is the vapor mass flow rate leaving the cathode, $W_{v, c a, g e n}$ is the rate of vapor generated in the fuel cell reaction, $W_{l, c a, \text { out }}$ is the rate of liquid water leaving the cathode, and $W_{v, m e m b r}$ is flow rate of water transfer across the membrane.

The oxygen partial pressure which affects the stack voltage can be calculated from these states using the ideal gas law. The mass flow rates with subscript in are calculated from $W_{\text {sm,out }}$ and the air thermodynamic properties. The amount of oxygen reacted or used in the reaction $W_{O 2, \text { react }}$ is a function of the stack current $I_{f c}$, which is considered in this work as a disturbance input.

$$
W_{O 2, \text { react }}=M_{O 2} \frac{n I_{f c}}{4 F}
$$

Where $n$ is the stack cells number, $M_{O 2}$ is the oxygen molar mass, and $F$ is the Faraday number.

The mass flow rates with subscript out are functions of the states $\left(m_{O 2, c a}, m_{N 2, c a}\right.$, and $\left.m_{w, c a}\right)$ and the cathode outlet flow, which is a function of the pressure downstream, i.e. return manifold pressure $p_{r m}$. The function in the linear nozzle equation is in the same form as (13)
$W_{c a, o u t}=k_{c a, o u t}\left(p_{c a}-p_{r m}\right)$

where $k_{c a, \text { out }}$ is the return manifold nozzle constant and $p_{c a}$ is the pressure of the cathode.

The return manifold is an air storage volume similar to the supply manifold, but the temperature changes can be neglected. The return manifold pressure dynamic is given by

$\frac{d p_{r m}}{d t}=\frac{R_{a} T_{r m}}{V_{s m}}\left(W_{c a, o u t}-W_{r m, o u t}\right)$

where $T_{r m}$ is the gas temperature in the return manifold and $V_{r m}$ is the return manifold volume. The return manifold outlet flow $W_{r m, o u t}$ is calculated by a nonlinear nozzle equations.

As shown in (14) and (15), the stack electrical current will cause the oxygen partial pressure to drop inside the cathode volume, which reduces the stack efficiency and also increases the risk of oxygen starvation. To fill the oxygen, the compressor has to increase the air flow to the supply manifold. However, the cathode oxygen cannot be replenished instantaneously since the dynamics of the compressor, the supply manifold, and the cathode volume are affected. The return manifold valve opening can be used to alter the cathode oxygen transient response by closing it down or opening it up during transients. Depending on the speed and the coordination between the compressor control and the return manifold valve opening, the recovery speed of the oxygen partial pressure is modified.

For the air management control, the controlled variable is the oxygen excess ratio

$\lambda_{O 2}=\frac{W_{O 2, \text { in }}}{W_{O 2, \text { react }}}$

where $W_{O 2, \text { in }}$ is the oxygen supplied to the cathode volume, and $W_{O 2, \text { react }}$ is the oxygen consumed in the reaction. A low value $\lambda_{O 2}$ means excessive oxygen depletion in the cathode (oxygen starvation) which results in the decrease of the stack voltage and the delivered power as well as shortening the fuel cell stack life. For simplicity reasons $\lambda_{O 2}=2$ is considered as an optimal set-up value as shown in Fig. 4. This means that the control problem is a regulation one, i.e. the main goal is to keep the output of the whole closed loop system at the level $\lambda_{O 2}$, regardless of the current required by the load, which is considered as an output disturbance.

The fuel cell system input variable is the compressor motor voltage $v_{c m}$

\section{EMULATOR IMPLEMENTATION SCHEME}

A fuel cell system air management has to comply with the requirement that $\lambda_{O 2}=2$. Since the underlying problem is a regulation problem, meaning that a constant $\lambda^{*}{ }_{\mathrm{O} 2}$ is given to the system, a simple solution is the use of a PI controller of the air flow rate, which would guarantee zero steady-state error of the linearized system as well as its stability [1]. 


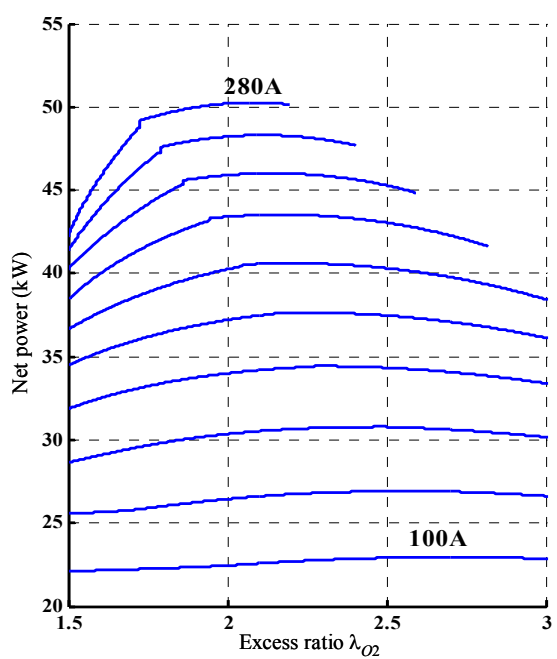

Fig. 4. System net power at different stack current and oxygen excess ratios.

Figure 5 shows the implemented $\lambda_{O 2}$ control scheme. The output of the PI $\lambda_{O 2}$ controller is the compressor motor reference voltage $v_{\mathrm{cm}}$. It should be noticed that the coefficient $\lambda_{O 2}$ is not a measured variable, but is inferred by the nonlinear model of the fuel cell system, which would then act as an observer of the real value. In the application, it is assumed that the fed-back $\lambda_{O_{2}}$ coincides with the real value [1].

The proposed fuel cell system emulator is then experimentally implemented and is based on the following main components:

1) The dynamic model block of the entire FC system with its auxiliaries (Fig. 1). The model two inputs are the oxygen excess ratio $\lambda^{*}{ }_{O 2}$ and the electric current required by the load $I_{F C}$. The stack temperature $T$ is considered constant. The output is the reference value of the stack voltage $v_{\text {ref }}$.

2) A DC-DC full bridge converter.

3) A state-space controller which processes the signals $v_{\text {ref }}$ and $v_{C}$ and gives the corrected value of the duty cycle $\alpha$ to the DC-DC converter in order to have the voltage chopper $v_{C}$ tracking $v_{r e f}$.

\section{EXPERIMENTAL RESULTS}

Figure 6 shows the proposed fuel cell system emulator that has been built-up.

The DC-DC IBGT full bridge converter has a rated power of $150 \mathrm{~W}$ with DC link voltage $V_{D C}=15 \mathrm{~V}$ and a rate current $I_{F C E}=10 \mathrm{~A}$. The system emulates therefore a PEMFC system with 381 cells.

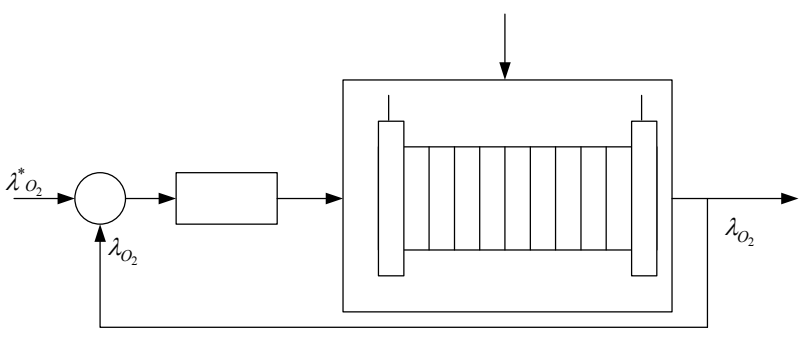

Fig. 5. Block diagram of the PI $\lambda_{O 2}$ control scheme.

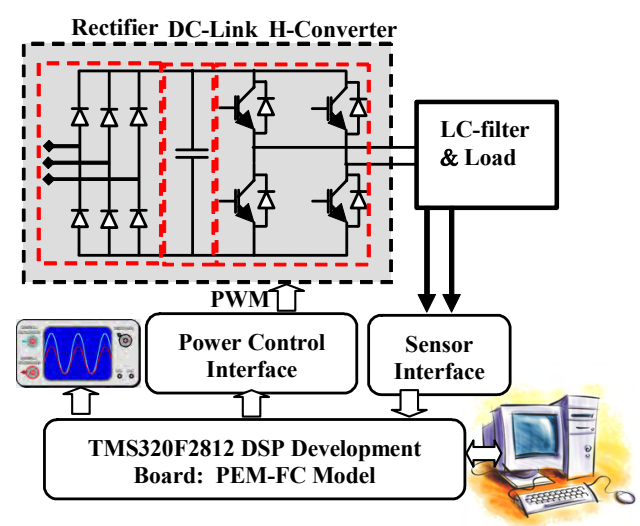

(a) Setup details.

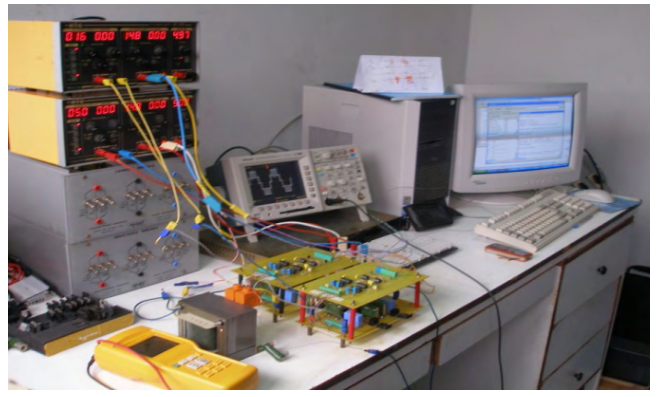

(b) Setup picture.

Fig. 6. Experimental setup.

In order to make the experimental results consistent with those of the model, the output current of the emulator has been scaled up by the factor 130 , so as to have a current ranging from 0 to $700 \mathrm{~A}$, while the output voltage of the emulator has been scaled up by the factor $381 / 15$ so as to have a voltage ranging from 0 to $500 \mathrm{~V}$.

Experimental results have been performed in a MatlabSimulink ${ }^{\circledR}$ environment adopting the FCS emulator. The entire FCS system model, including the FC stack and its auxiliaries, as well as the DC-DC converter control system, has been implemented on a DSP320F2812 board.

The fuel cell operating characteristics are depicted in Fig. 7. It shows both simulation (continuous lines from the fuel cell model) and experimental results (points from the DC-DCbased converter built-up emulator).

These characteristics have been acquired averaging the FC different voltages versus current (including all the auxiliaries) for three different cathode pressures at a constant operating temperature. It is then observed that simulation and experimental results are quite superimposed. The stack characteristics (various voltage losses in Figs. 7a to 7c) clearly show that they increase with current and decrease with cathode pressure for a given current.

The fuel cell system operating characteristics (Fig. 7d) show the different stack characteristics, respectively from those at lower pressure to those at higher ones for increasing values of current. These characteristics clearly illustrate the fact that the fuel cell voltage can be maintained constant by pressure variation for a variable load. 


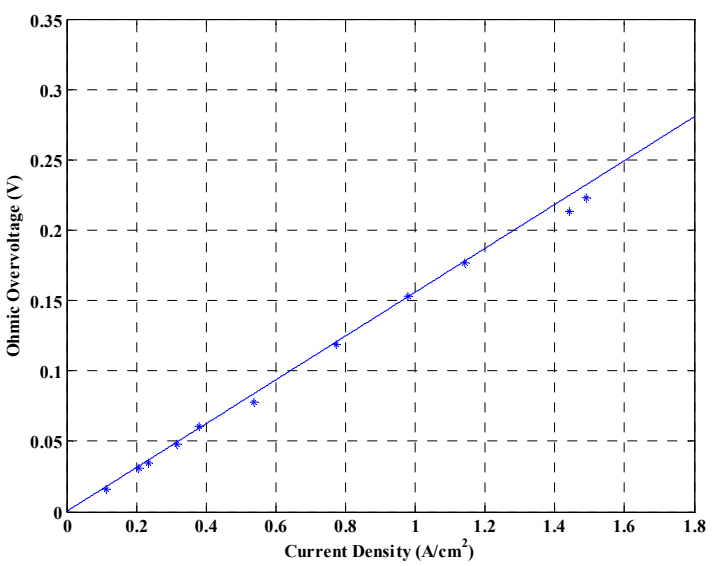

(a) Ohmic overvoltage.

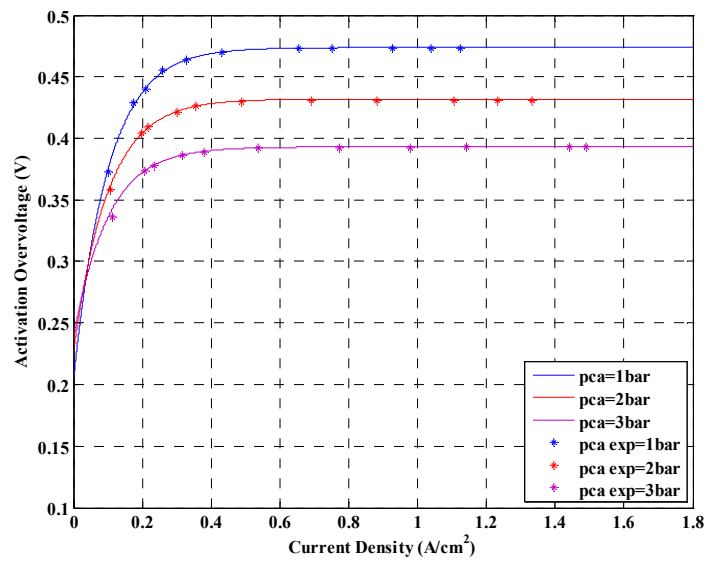

(b) Activation overvoltage.

\section{CONCLUSION}

This paper dealt with a DC-DC-based converter emulator of a proton exchange membrane fuel cell system including all its auxiliaries. Indeed, the PEMFC system is emulated by a fullbridge converter experimentally built-up and controlled within a DSP2812 environment.

The obtained experimental results and compared to the ones from a fuel cell model clearly confirm the effectiveness of the proposed emulator. Moreover, various fuel cell characteristics can be easily customized by inputting the fuel cell data.

\section{REFERENCES}

[1] G. Marsala et al., "A prototype of a fuel cell PEM emulator based on a buck converter," Applied Energy, vol. 86, n¹0, pp. 2192-2203, October 2009.

\section{APPENDIX}

\section{Fuel CELl System Parameters}

$\rho_{m, d r y}\left(0.002 \mathrm{~kg} / \mathrm{cm}^{3}\right), M_{m, d r y}(1.1 \mathrm{~kg} / \mathrm{mol}), t_{m}(0.01275 \mathrm{~cm}), n$ (381 cells), $A_{f c}\left(280 \mathrm{~cm}^{2}\right), J_{c p}\left(5.10^{-5} \mathrm{kgm}^{2}\right), v_{a n}\left(0.005 \mathrm{~m}^{3}\right), v_{s m}\left(0.02 \mathrm{~m}^{3}\right), v_{r m}\left(0.005 \mathrm{~m}^{3}\right)$, $C_{d, r \mathrm{~m}}\left(0.0124 \mathrm{~m}^{2}\right), A_{t, r m}\left(0.002 \mathrm{~m}^{2}\right), K_{s m, \text { out }}\left(0.3629 .10^{-5} \mathrm{~kg} / \mathrm{mol}\right)$,

$K_{\text {ca,out }}\left(0.2177 .10^{-5} \mathrm{~kg} / \mathrm{mol}\right), k_{v}\left(0.0153 \mathrm{~V} / \mathrm{rad} \mathrm{sec}^{-1}\right), k_{t}(0.0153 \mathrm{Nm} / \mathrm{A})$, $R_{c m}(0.82 \Omega), \eta_{c m}(98 \%)$

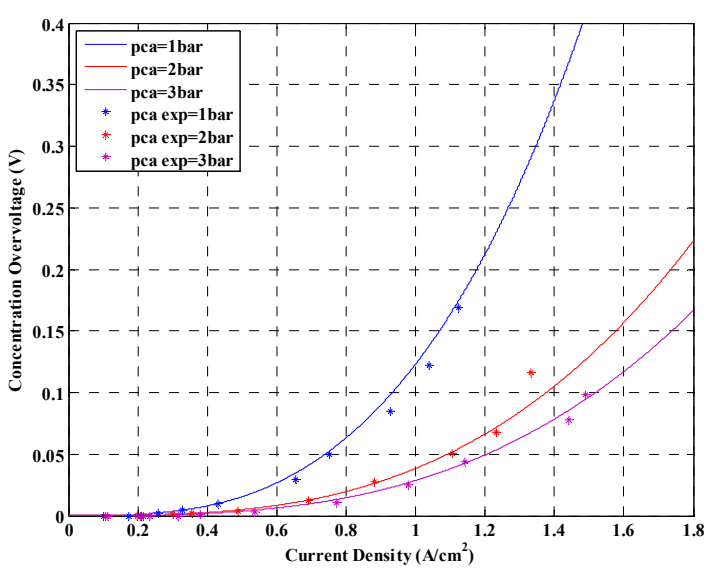

(c) Concentration overvoltage.

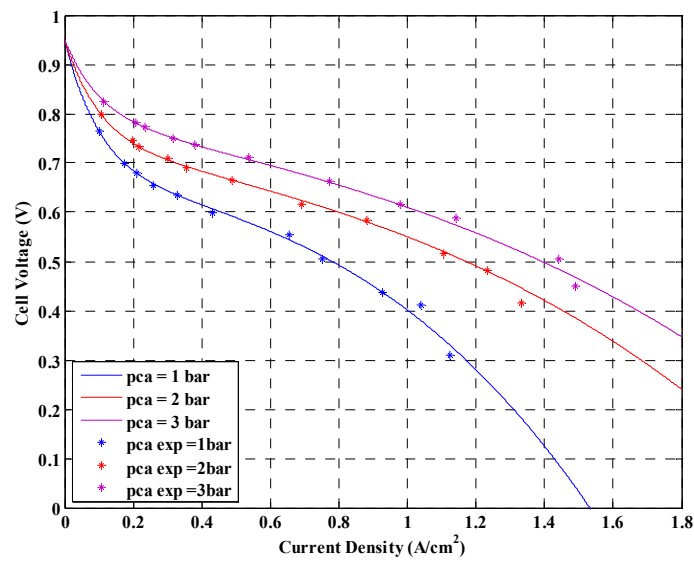

(d) Fuel cell system working characteristic.

Fig. 7. Stack characteristics at different cathode pressures.

[2] M. Cirrincione et al., "Real time simulation of renewable sources by model-based control of DC/DC converters," in Proceedings of the ISIE'08, Cambridge (UK), pp. 1548-1555, June -July 2008.

[3] F. Gao et al., "PEM fuel cell stack modeling for real-time emulation in hardware-in-the-loop applications," IEEE Trans. Energy Conversion, vol. 26, n¹, pp. 184-194, March 2011.

[4] A. Gebregergis et al., "Implementation of fuel cell emulation on DSP and dSPACE controllers in the design of power electronic converters," IEEE Trans. Industry Applications, vol. 46, n¹, pp. 285-294, JanuaryFebruary 2010

[5] J. Larminie et al., Fuel Cell Systems Explained, John Wiley \& Sons, West Sussex, England, 2000.

[6] J.C. Amphlett et al., "Performance modeling of the Ballard Mark IV solid polymer electrolyte fuel cell: II. Empirical model development," Journal of Electrochemical Society, vol. 142, n²1, pp. 9-15, 1995.

[7] J.H. Lee et al., "Modeling electrochemical performance in large scale proton exchange membrane fuel cell stacks," Journal of Power Sources, vol. $70, \mathrm{n}^{\circ} 2$, pp. 258-268, February 1998.

[8] K. Kordesch et al,. Fuel Cells and Their Applications, VCH, Weinheim, Germany, 1996.

[9] F. Laurencelle et al., "Characterization of a Ballard MK5-E proton exchange membrane fuel cell stack," Fuel Cells, vol. 1, n 1 , pp.66-71, 2001.

[10] J.C. Amphlett et al., "Parametric modelling of the performance of a 5kW proton-exchange membrane fuel cell stack," Journal of Power Sources, vol. 49, n¹-3, pp. 349-356, April 1994.

[11] T.E. Springer et al., "Polymer electrolyte fuel cell model," Journal of Electrochemical Society, vol. 138, n8, pp.2334-2342, 1991.

[12] T.V. Nguyen et al., "A water and heat management model for protonexchange-membrane fuel cells," Journal of Electrochemical Society, vol. $140, n^{\circ} 8$, pp. $2178-2186,1993$. 